\title{
Granular cell tumor of the tongue
}

\author{
Dilde granüler hücreli tümör \\ Alper Kanmaz', Yunus Feyyat Sakin², Togay Müderris', Nazım Bozan³, Muzaffer Kırış \\ ${ }^{1}$ Department of Otorbinolaryngology, Ankara Atatiirk Training and Research Hospital, Ankara, Turkey \\ ${ }^{2}$ Department of Otorbinolaryngology, Özel Uzmanlar Tip Merkezi, Şanhurfa, Turkey \\ ${ }^{3}$ Department of Otorbinolaryngology, Faculty of Medicine, Yiiziincii Yul Universitesi, Van, Turkey
}

\begin{abstract}
Granular cell tumor (GCT) is a rare benign neoplasm that is observed in oral cavity mostly in head-neck part or especially on the tongue. This lesion is generally observed as a solitary nodule with unidentified boundaries and it may reside in different areas of the body. The presented case is a 35 -year-old male patient who referred with a problem of indolent lesion on his tongue. Excisional biopsy has been applied to the patient under general anesthesia. There was no complication observed in surgical operation and during post-operative period. There were no symptoms observed on the sixth month of post-operative period. In this paper, a case that has unidentified boundary of tongue placement which includes cystic lesion and identified by a GHT diagnosis has been presented by reviewing the up-to-date studies.
\end{abstract}

Keywords: Granular cell tumor, tongue, neoplasm.

\begin{abstract}
Özet
Granüler hücreli tümör (GHT), çoğunlukla baş-boyun bölgesi ile özellikle dilde olmak üzere oral kavitede yerleşim gösteren ve nadir görülen iyi huylu bir neoplazmadır. Lezyon genellikle sınırları belirsiz, soliter bir nodül şeklinde görülmekle birlikte, vücudun değişik bölgelerinde bulunabilmektedir. Sunulan olgu, dilde ağrısız kitle şikâyeti ile başvuran 35 yaşında bir erkek hasta idi. Hastaya genel anestezi altında eksizyonel biyopsi uyguland. Operasyonda ve postoperatif takibinde komplikasyonla karşılaşılmadı. Hasta postoperatif altıncı ayında semptomsuzdu. Bu makalede dil yerleşimli sınırları belirsiz, kistik lezyonlu, histopatolojik olarak GHT tanısı alan bir olgu, güncel makaleler gözden geçirilerek sunulmuştur.
\end{abstract}

Anahtar sözcükler: Granüler hücreli tümör, dil, neoplazi.
Granular cell tumor (GCT) is a rarely seen neoplasia, but frequently of benign nature. They can be seen localized within subcutaneous, and subepithelial tissue. Almost half of the granular cell tumors develop in the head and neck surgery. They are most frequently seen in the tongue, and oral cavity. ${ }^{[1,2]}$ Tumor is especially seen in $3-5$ decades. ${ }^{[3,4]}$ In this paper, we presented a cystic tongue lesion with definite contours, and a histopathologic diagnosis of GCT.

One of the most important characteristics of the tumor is the difficulty it poses in the differential diagnosis from epidermoid cell carcinoma because of its manifestations of pseudoepitheliomatous hyperplasia seen on the surface of the lesion. ${ }^{[1]}$ Granular cell tumor was first defined by Abrikossof in 1926. ${ }^{[5]}$ Abrikossof thought that the tumor originated from myoblasts, and accordingly termed the tumor as granular cell myoblastoma. However according to currently accepted opinion, GCT stems from neural structures. ${ }^{[5]}$

Typical histopathologic feature of the tumor is its apparent superficial pseudoepitheliomatous hyperplasic lesions. Hence it is difficult to discriminate GCT from epidermoid cell carcinoma. In this paper, GHT was revisited in consideration of a mass lesion of tongue.

\section{Case Report}

A 35-year-old male patient presented to our clinic with a painless, slow-growing indolent mass he observed on his tongue for a long time. Bimanual examination of his tongue
Correspondence: Yunus Feyyat Sakin, MD. Department of Otorhinolaryngology, Ozel Uzmanlar Tip Merkezi, Sanliurfa, Turkey.

e-mail: feyyats@hotmail.com

Received: August 7, 2013; Accepted: November 20, 2013; Published online: May 5, 2014
Online available at:

www.jmedupdates.org doi:10.2399/jmu.2014001008 QR code: 
revealed an approximately $6 \times 5 \mathrm{~cm}$ mass with regular contours elevated from the mucosal surface, but insensitive to palpation (Fig. 1).

Other ENT examination results were within physiologic limits. A lymphadenopathic neck mass was not palpated, and the mass was excised totally under general anesthesia (Fig. 2).

Pathologic specimen excised was examined histopathologically, and hematoxylin-eosin revealed pseudohyperplasic multilayered epithelium demonstrating hyperkeratosis, and patchy areas of parakeratosis, and acanthosis, and subepithelial tumoral lesions. Immunohistochemical staining disclosed strong immunopositivity for S-protein, while a weak immunopositivity was observed for CD 68. In the light of these findings, histopathologic diagnosis of GCT was reported. Any evidence of tumor was not encountered all over the surgical margin of the excised mass. On the first postoperative day the patient was discharged, and postoperative follow-up examination performed at 6th month could not detect any sign of recurrence. Epithelium covering the tumoral mass demonstrated pseudoepitheliomatous hyperplasia. In its differential diagnosis from squamous cell carcinoma, this characteristic feature should be taken into consideration. Optimal treatment approach is a relatively broader local excision. Surgical margins should be devoid of tumor, otherwise recurrence will be an unavordable complication.

\section{Discussion}

Granular cell tumor is a rarely seen tumor which may be observed in any part of the body. It is 2 times more frequently seen in women, and its highest incidence is observed between the fourth and sixth decades. Though the tumor is typically seen as a small, insensitive solitary lesion, it can be found in various tissues in $10-15 \%$ of the patients. ${ }^{[5,6]}$ Most of GCTs are benign with rarely seen local recurrences. Malignant types have been found in $1-2 \%$ of the cases. Malignant tumors are usually larger than $5 \mathrm{~cm}$ in diameter, demonstrate rapid growth, and carry risk of metastasizing into other anatomic structures. Histopathologically, necrosis, and increase in mitotic activity are seen. These tumors are differentiated from benign types with mitotic characteristics, atypical and destructive growth patterns. ${ }^{[7]}$ During histopathologic examination of our patient, findings suggestive of malignant transformation were not observed.

Granular cell tumors were first described by Abrikossoff in 1926. Abrikossoff named this tumor as granular cell myoblastoma because of its microscopic characteristics resembling to muscle fibrilles. ${ }^{[7]}$ Histologically, tumor

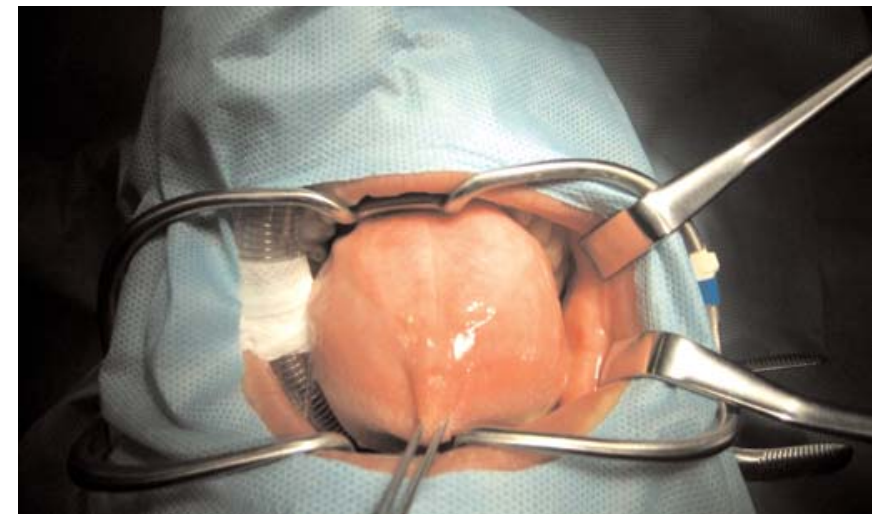

Fig. 1. Preoperative appearance of a patient who referred to our clinic with a swollen tongue.

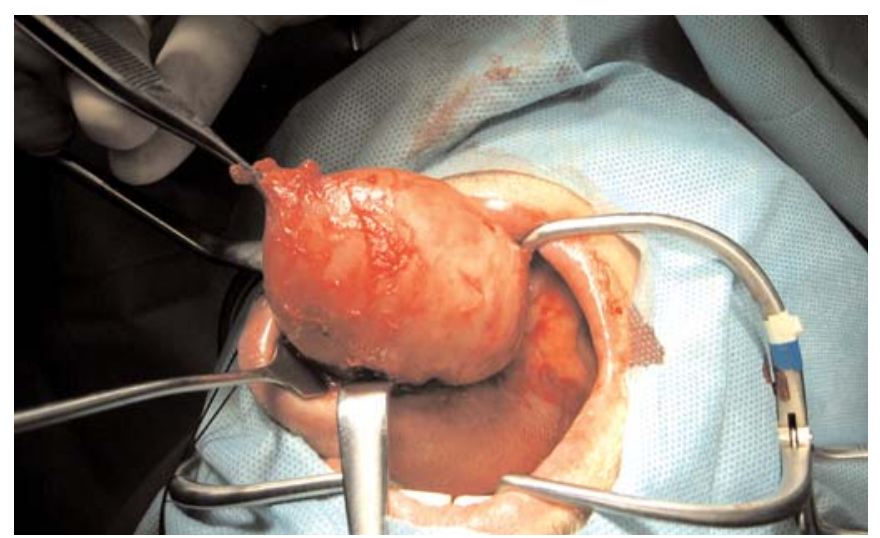

Fig. 2. Intraoperative appearance of the mass on the tongue.

is composed of round and polygonal cells with small centrally located vesicular nuclei, and granular eosinophilic cytoplasm.

Epithelial pseudoepitheliomatous hyperplasic layer covering all over the tumoral mass should not be confused with squamous cell carcinoma. ${ }^{[6,7]}$

Many authors have proposed various opinions about the source of GCH. Histiocytes, fibroblasts, and mesenchymal cells have been indicated as origin of the tumor. However, according to currently accepted opinion, tumor is of neurogenic origin. ${ }^{[5]}$ Manara demonstrated neurotubuli, and neurofilaments in the ultrastructure of $\mathrm{GCH}{ }^{[7]}$

Enzinger and Weiss proposed immunopositive staining properties of S-100 protein, CD 68, neuron specific enolase as a strong evidence demonstrating neural origin of the tumor. ${ }^{[6]}$

Granular cell tumor is immunopositive for S-100 protein, vimentin, myelin basic protein, and immunonegative for myogenic markers. In the light of these findings, associ- 
ation of GCT with small nerves supports correlations between GCTs, and Schwann cell neoplasms. ${ }^{[7]}$ In our case, S-100 protein staining revealed cells with positively stained granules, and granular eosinophilic cytoplasm

Granular cell tumors are usually observed as solid nodules with indeterminate contours, while the contours of the present case are noted as a cystic lesion with distinct boundaries. Differential diagnosis of GCTs from other benign tumors can be made easily. It differentiates from rhabdomyoma in that it contains granular cytoplasm but lacks crossbanding, and glycogen. Absence of fat droplets in GCTs, discriminate them from hibernoma, and fibroxanthoma. ${ }^{[6]}$ Ideal treatment modality is a larger local excision. If the tumor grows rapidly to more than $4 \mathrm{~cm}$ in diameter, then it is recommended to decide on regional lymph node dissection, and to detect any metastatic lesion (if any) during radiological evaluation. In malignant cases, effectiveness of chemotherapy and radiotherapy was not established.$^{[8]}$ Malignant granular cell tumor can be seen in 1-2\% of the cases. In these cases, tumors are generally larger than $5 \mathrm{~cm}$ in diameter with a tendency to rapid growth, and a higher risk of metastasis. Microscopically necrosis, and increases in mitotic activity are seen. ${ }^{\left[{ }^{[9]}\right.}$ Surgical margins should be free of tumoral involvement, otherwise recurrence will be unavoidable.

Lack et al. reported recurrence rate as $8 \%$, despite adequate surgical excision. ${ }^{[10]}$ Diagnosis of granular cell tumor should be made by histopathologic examination. Tumor cells consist of larger polyhedral cells containing excess number of eosinophilic granules, and small centrally located nuclei. ${ }^{[11]}$

Histopathologic examination findings of our case did not suggest malignancy. Pseudo epithelium pseudoepitheliomatous hyperplasia of the epithelial layer surrounding the tumor is seen in $75 \%$ of granular cell tumors. ${ }^{[1]}$ Thus, it can be confused with squamous cell carcinoma. In fact these two cancer types have nothing in common. In this study, reactive and hyperplasic alterations occur on the surface of granular cell tumor without any transformation into squamous cell carcinoma. Because of this characteristic feature of the tumor, a close collaboration with the pathologist should be instituted, and pathologist should be informed about the location, and surface characteristics of the tumor.
Granular cell tumor is a rarely encountered tumor without any distinct symptomatology, but it can be confused with epidermoid carcinoma because of pseudoepitheliomatous hyperplasia seen in nearly $75 \%$ of the cases. Reactive and hyperplasic alterations occur in the squamous epithelium on the surface of GCT, but GCT does not transform into squamous cell carcinoma. Therefore as a critically important fact, accurate histopathologic examination requires close collaboration between clinicians and pathologists, and the pathologists should be informed about clinical properties, location, and external appearance of the tumor.

Conflict of Interest: No conflicts declared.

\section{References}

1. Compagno J, Hyams VJ, Ste-Marie P. Benign granular cell tumors of the larynx: a review of 36 cases with clinicopathologic data. Ann Otol Rhinol Laryngol 1975;84:308-14.

2. Kershisnik M, Batsakis JG, Macka B. Granular cell tumors. Ann Otol Rhinol Laryngol 1994;103(5 Pt 1):416-9.

3. Goldenberg D, Ardekian L, Rachmiel A, Pelet M, Joachims HZ, Laufer D. Carsinoma of the dorsum of the tongue. Head Neck 2001;22:190-194.

4. Kawaida M, Fukuda H, Kohno N. Granular cell tumor arising nearly simultaneously in the larynx and subcutaneus cervical region. Ear Nose Throat J 2000;79:162-6.

5. Oğuz F, Öz F, Öktem F, Erdamar S. Granular cell tumor [Article in Turkish]. Turkish Archives of Otolaryngology 1999;37:51-3.

6. Enzinger FM, Weiss SW. Benign tumors of peripheral nerves. In: Enzinger FM, Weiss SW, eds. Soft tissue tumors. 3rd ed. St. Louis: Mosby-Year Book; 1995:821-88.

7. Miettinen M, Weiss SW. Soft tissue tumors. In: Damjanov I, Linder J, editors. Anderson's pathology. 10th ed. St. Louis: MosbyYear Book; 1996. p. 2480-530.

8. Curtis BV, Calcaterra TC, Coulson WF. Multiple granular cell tumor: a case report and review of the literature. Head Neck 1997;19:634-7.

9. Liu K, Madden JF, Olatidoye BA, Dodd LG. Features of benign granular cell tumor on fine needle aspiration.Acta Cytologica 1999;43:552-7.

10. Lack EE, Worsham GF, Callihan MD, et al. Granular cell tumor: a clinicopathologic study of 110 patients. J Surg Oncol 1980;13: 301-16.

11. Franzen S, Stenkvist B. Diagnosis of granular cell myoblastoma by fine-needle aspiration biopsy. Acta Pathol Microbiol Scand 1968; $72: 391-5$

This is an open access article distributed under the terms of the Creative Commons Attribution-NonCommercial-NoDerivs 3.0 Unported (CC BYNC-ND3.0) Licence (http://creativecommons.org/licenses/by-nc-nd/3.0/) which permits unrestricted noncommercial use, distribution, and reproduction in any medium, provided the original work is properly cited.

Please cite this article as: Kanmaz A, Sakin YF, Müderris T, Bozan N, Kırıs M. Granular cell tumor of the tongue. J Med Updates 2014;4(1):37-39. 